\title{
Biomass Energy Outlook in Malaysia using Functions of Innovation Systems
}

\author{
Bemgba Bevan Nyakuma ${ }^{1,2}$ \\ ${ }^{1}$ Centre of Hydrogen Energy, Institute of Future Energy, \\ Universiti Teknologi Malaysia, 81310 Skudai, Johor Bahru, Malaysia. \\ ${ }^{2}$ Department of Chemical Engineering, Faculty of Chemical \& Energy Engineering, \\ Universiti Teknologi Malaysia, 81310 Skudai, Johor Bahru, Malaysia. \\ Tel. +6(0)149890390; E-mail: bnbevan2@live.utm.my, bbnyax1@gmail.com
}

\begin{abstract}
Malaysia generates significant quantities of Oil Palm Wastes (OPW) which can be potentially valorised into sustainable bioenergy as envisaged by the National Biomass Strategy (NBS-2020). Despite significant investments, policy directives and government support, the valorisation of OPW into bioenergy has remained low exacerbating waste management challenges. Therefore, the strategies and impediments to the rapid bioenergy development and bioelectricity generation from OPW require practical assessment. Therefore, this paper examines the level of development and diffusion of the biomass innovation system in Malaysia based on the Functions of Innovations Systems (FIS) approach developed by Dutch and Swedish researchers. Furthermore, the key factors hindering biomass energy technologies implementation in Malaysia and potential solutions were identified, highlighted and examined. Based on the FIS analysis the functions; entrepreneurial activities, knowledge development, and resources mobilization functions are well established in the Malaysian biomass innovation system (BIS). However, the functions of guidance of search; creation of legitimacy; knowledge diffusion and market formation are underdeveloped resulting in the low penetration of bioenergy in Malaysia. Other factors include; fossil fuel subsidies, numerous or conflicting energy policies and weak collaboration between academia and the industry. The outlined challenges can be addressed by revising fuel subsidies, Feedin tariffs, RETs implementation, roles of supervisory agencies, and bureaucratic procedures for access to funds for research and development of bioenergy in Malaysia.
\end{abstract}

Keywords: Biomass, Functions, Innovation Systems, Renewable Energy, Malaysia. 


\section{Introduction}

Energy is a crucial determinant of socio-economic growth and sustainable development [1]. Currently, the fossil fuels utilization comprises $82 \%$ of global energy mix with coal (64\%), oil (19\%) and natural gas (17\%) accounting for the total economically recoverable sources of energy [2,3]. Conversely, the International Energy Agency (IEA) predicts fossil fuel utilization will decrease by 2035 due to rapidly depleting reserves and growing concerns about environmental degradation and greenhouse gas $(\mathrm{GHG})$ emissions $[3,4]$. This has catalysed the search for alternative sources of low-cost, non-polluting, and renewable energy to supplement fossil fuels and ensure environmental sustainability $[5,6]$. This will potentially stimulate growth in the development, diffusion and primary energy demand for renewables such as solar, hydropower, wind, ocean tidal, geothermal and biomass energy. As a result, the IEA projects that the global energy demand for renewables will be significantly influenced by emerging economies like China and India accounting for $90 \%$ of net energy demand growth by 2035 [7]. It is therefore envisaged that the utilization of RETs will critically influence the future dynamics of the global energy mix [8]. Similarly, the IRENA (international renewable energy agency) posits that the implementation of RETs will potentially account for $36 \%$ of the global energy mix by 2030 . According to the report, biomass energy will account for the largest share based on soaring demand which is expected to exceed 108 EJ by 2030 . This will potentially account for $60 \%$ of total RETs utilization around the globe [9].

Currently, biomass is ranked as the $4^{\text {th }}$ largest global energy source comprising 10 $14 \%$ or 51 EJ of global energy supply [10-12]. The growing interest in biomass can be attributed to its wide global distribution, carbon neutrality and clean energy potential which results in zero $\mathrm{CO}_{2}$ net emissions during conversion [13-15]. Biomass can be effectively converted into clean and renewable liquid, solid and gaseous fuels, energy and chemicals using a variety of feedstocks [16-19]. According to IRENA, the supply of biomass feedstock will exceed 145 EJ by 2030 with agricultural waste residues accounting for 37-66 EJ, energy crops 33-39 EJ and forestry residues 24-43 EJ particularly from developing countries in Asia [9]. 
Malaysia is the second largest producer and exporter of palm oil accounting for $31 \%$ of global output $[20,21]$. Currently, oil palm (Elaeis guinnensis) is cultivated on over 5 million hectares of arable land production which yields 80 million tons of fresh fruit bunches (FFB) annually [22]. The FFB is typically processed into crude palm oil (CPO) and palm kernel oil (PKO) for utilization in the food, fuels, and chemical industries $[23,24]$. This value creation process generates large quantities of lignocellulosic waste comprising empty fruit bunches (EFB), mesocarp fibre (MSF), palm kernel shell (PKS), palm fronds (OPF) and palm trunks (OPT) $[25,26]$. The resulting solid oil palm waste (OPW) presents significant disposal and pollution management challenges for the palm oil industry [27-29]. Currently, the OPW in Malaysia is utilised for organic fertilizer, soil enhancement [30] and boiler fuel for the cogeneration of steam and electricity in oil palm mills (OPM) [31, 32]. However, large proportions of OPWs are simply dumped in open fields, indiscriminately burned or landfilled [33]. The inefficiency of these waste conversion techniques has exacerbated the rate of greenhouse gas (GHG) emissions, atmospheric pollution, and environmental degradation [34]. As a result, Malaysia is the $24^{\text {th }}$ largest contributor to global GHG accounting for 250 million tons of $\mathrm{CO}_{2}$. This arises from the $345 \%$ increase in $\mathrm{CO}_{2}$ emissions recorded from 1990 - 2015 originating primarily from agriculture [35]. The underlying dynamics emphasize the urgent need for research into novel, low cost, and efficient technologies for the disposal, management, and valorisation of OPW.

Consequently, the Government of Malaysia (GoM) established the National Biomass Strategy (NBS-2020) in 2011 to address the challenges of OPW disposal and management [36]. The policy aims to valorise 20 million tons of dry biomass, reduce GHGs, generate renewable energy and create 66,000 jobs. One promising approach is to explore the conversion of OPW into clean, renewable and sustainable bioenergy and biofuels. However, the transition from fossil fuels to clean bioenergy in the Malaysian energy economy will require a paradigm shift from status quo, by addressing the numerous techno-economic and socio-political challenges hampering clean energy and power generation technologies in the country [36]. The challenges of developing and implementing RETs can be critically examined using sociotechnical analytical concepts such as the Functions of Innovations Systems (FIS) developed by researchers in the Netherlands and Sweden. This is an empirical concept designed to analyse and evaluate 
the societal subsystems, actors, and institutions that contribute to the development of an innovation. The concept can be used to analyse the performance of technological innovations systems using a set of "functions" called the "functions of innovation systems"[37]. An innovation system is the sum of all the hardware, software, institutions and economic structures that influence the rate and direction of socio-technological change $[37,38]$. This is vital for assessing the level of sustainable economic growth and technological development in any society [39]. Furthermore, the approach avails researchers with tools to map, establish functional patterns and feedback loops between the various functions within an innovation system [40, 41].

The FIS concept can stimulate the creation of policy instruments aimed at meeting the targets of the innovation system through in-depth analyses of system determinants, performance, and failures [39, 42]. The practicality of FIS has been successfully demonstrated by its application to a number of sociotechnical and energy innovation systems around the world. The study by Kamp [43] examined the socio-technical dynamics, prospects, and limitation of wind power in the Netherlands and Denmark. Likewise the FIS approach has been applied to examine the prospects and challenges of biomass energy as an innovative RET. Negro et al. [44] examined the successes and failures of the biomass innovation system (BIS) in the Netherlands using FIS. A different study by Negro et al. [45] identified, highlighted and examined challenges of biomass digestion as an emerging innovation system in the Netherlands. Similarly, the success of biomass digestion as an emerging innovative renewable technology in Germany has been examined by FIS [46]. The results of the studies have demonstrated that FIS can be successfully applied to examine the level of development, diffusion, and utilization of biomass as an innovative RET. Furthermore, the FIS can present insights into the sociotechnical dynamics, institutional framework and policy direction of energy systems. However, the FIS approach has never been used to analyse RETs or innovations system outside the European continent despite its success. Furthermore, there is limited knowledge on the status of biomass energy as described in Malaysia's energy policies such as the Fifth Fuel Policy (5FP) of the $8^{\text {th }}$ Malaysia Plan (8MP) and the Renewable Energy Policy and Action Plan (REPAP) [47, 48].

Therefore, the FIS approach will be applied to examine the level of development and diffusion of biomass energy in Malaysia. It is envisaged that the concept will provide 
a systematic framework for examining biomass in Malaysia as an innovation system. Therefore, this study is aimed at identifying the key network of stakeholders, policies directives and innovative technologies that influence biomass energy in Malaysia through the set of 'functions' within Functions of Innovations Systems (FIS) approach. The study will also identify and highlight key sociotechnical and technological challenges hindering its implementation in Malaysia.

\section{Functions of Innovation Systems (FIS)}

The "Functions of Innovation Systems" (FIS) approach is governed by a set of "functions" namely; Entrepreneurial activities, Knowledge development, Knowledge Diffusion, Guidance of search, Market formation, Resources Mobilization, and Creation of legitimacy. This methodology can be used to identify the networks of key actors and institutions collectively known as "stakeholders" responsible for the development and diffusion of an innovation system. The stakeholders in any innovation system can be categorised into three broad groups [37]; Technology Producers, Technology Regulators, and Technology Users.

The technology producers consist of all the entrepreneurs, networks or clusters of technology companies within the innovation system. Conversely, the organisations, ministries and government agencies that oversee government policy directives and implementation guidelines are termed technology regulators. Finally, the end users of the products and spin-off technologies are referred to as technology users or consumers. Furthermore, the designated roles of the actors, network, and institutions in an innovation system are reinforcing and complementary, thus creating a network of activities that can be categorised into a stakeholder map [37, 49]. A stakeholder map of the biomass innovation system (BIS) in Malaysia is presented in Figure 1. 


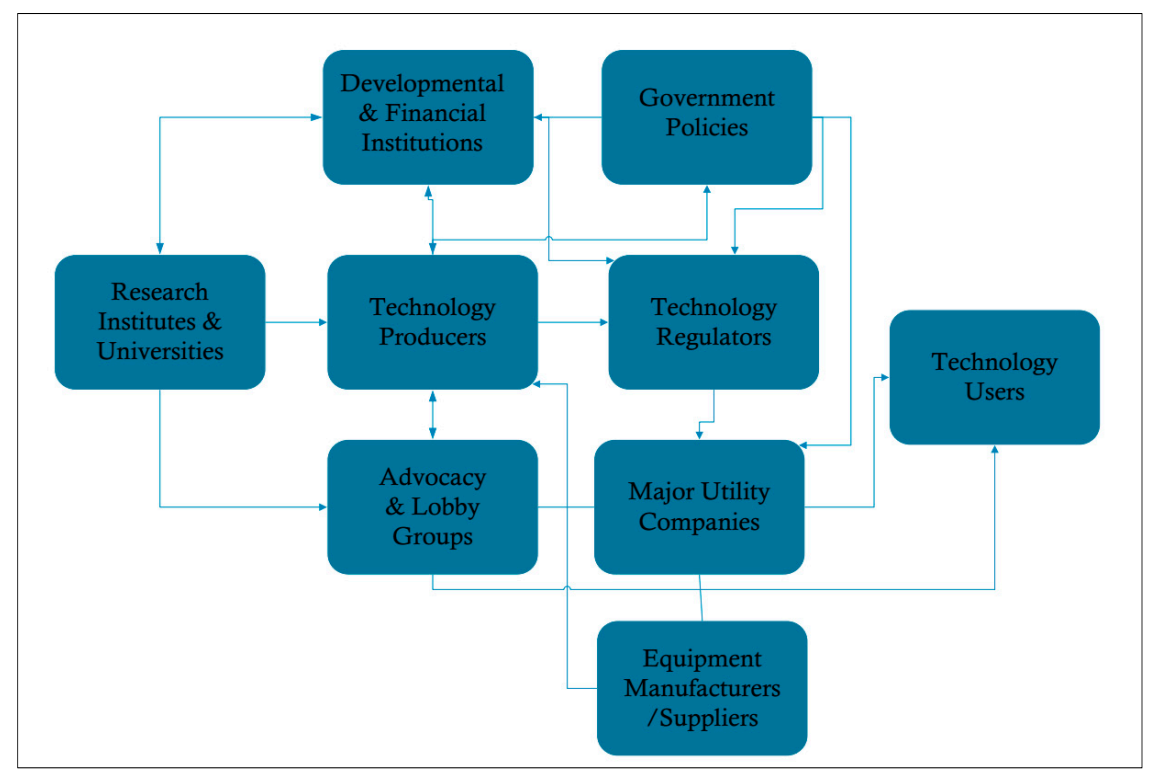

Figure 1. Stakeholder map for the Malaysian biomass innovation system.

The stakeholder map in presents an overview of the interdependencies between the major technological stakeholders comprising the producers, regulators, and users in innovation systems [49]. Based on this, the FIS will be employed to identify the key factors and stakeholders that influence the implementation of biomass energy technologies in Malaysia.

\subsection{Entrepreneurial Activities}

The entrepreneur plays a vital role in the success of an innovation system. The entrepreneur is responsible for conceiving and creating the innovative ideas that influence socioeconomic and technological change in any innovation system. The entrepreneur is also responsible for coordinating all the knowledge, networks and market potentials within an innovation system into business opportunities [37, 40]. In principle, entrepreneurs may either be new entrants looking to maximise the business potential of new technologies or established firms expanding their business portfolio. Essentially, entrepreneurs are risk takers involved in the development of new technologies [50]. Hence the success of an innovation system is greatly influenced by entrepreneurs and the network of functions within an innovation system [37]. Table 1 presents a list of the identified key actors notably entrepreneurs, organisations and government agencies in the biomass innovation system (BIS) in Malaysia. 
Table 1. Key stakeholders in the Malaysian biomass innovation system (BIS).

\begin{tabular}{|c|c|c|}
\hline Name of organisation, company or institution & Description & Role \\
\hline Alaf Ekspresi Sdn Bhd & Private Energy Company & $\mathrm{TP}$ \\
\hline Biomass Technology Group & Foreign Energy Company & $\mathrm{TP}$ \\
\hline Bio-power Sdn. Bhd & Private Energy Company & $\mathrm{TP}$ \\
\hline Bumi Biopower Sdn Bhd & Private Energy Company & $\mathrm{TP}$ \\
\hline Chubu Electric Power & Foreign Energy Company & $\mathrm{TP}$ \\
\hline Department of Environment & Government Ministry & TR \\
\hline Department of Statistics & Government Ministry & OT \\
\hline Genting Sanyen Power Bhd & Private Energy Company & $\mathrm{TP}$ \\
\hline IRIS WRP Eco Power Sdn Bhd & Private Energy Company & $\mathrm{TP}$ \\
\hline Jana Landfill Sdn Bhd & Private Energy Company & $\mathrm{TP}$ \\
\hline Kemaman Biomass Power (M) Sdn Bhd & Private Energy Company & $\mathrm{TP}$ \\
\hline Kina Biopower Sdn Bhd & Private Energy Company & $\mathrm{TP}$ \\
\hline Malaysian Agric. Research \& Dev Institute & Government Agency & OT \\
\hline Malaysian Palm Oil Board & Government Agency & TR \\
\hline Ministry of Energy, Green Technology \& Water & Government Ministry & TR \\
\hline Naluri Ventures Sdn Bhd & Private Energy Company & $\mathrm{TP}$ \\
\hline Palm Oil Institute of Malaysia & Government Agency & OT \\
\hline Petronas Group & National Energy Company & $\mathrm{TP}$ \\
\hline Potensi Gaya Sdn Bhd & Private Energy Company & $\mathrm{TP}$ \\
\hline Powertude Sdn. Bhd. & Private Energy Company & $\mathrm{TP}$ \\
\hline Recycle Energy Sdn Bhd & Private Energy Company & $\mathrm{TP}$ \\
\hline Sabah Electricity Sdn. Bhd & National Energy Company & $\mathrm{TP}$ \\
\hline Seguntor Bioenergy Sdn Bhd & Private Energy Company & $\mathrm{TP}$ \\
\hline Sarawak Electricity Supply Corporation & National Energy Company & $\mathrm{TP}$ \\
\hline Suruhanjaya Tenaga & Energy Commission & TR \\
\hline Sustainable Energy Development Authority & Government Agency & TR \\
\hline Tenaga Nacional Berhad & National Energy Company & TP \\
\hline TSH BioEnergy Sdn Bhd & Private Energy Company & TP \\
\hline
\end{tabular}

$T P, T R, \&$ OT represent Technology Producers, Technology Regulators, and Others respectively. 
As observed, the key stakeholders serve as producers, regulators or users of biomass energy in Malaysia. The producers in the innovation systems is responsible for creating bioenergy from biomass utilization based on the lignocellulosic pathway of the National Biomass Strategy (NBS-2020) [36]. This is based on the long-term objective to generate 1,340 MW of bioelectricity from Oil Palm Wastes (OPW) and wood waste utilization in biomass power plants [51]. Table 2 presents an overview of the biomass power plants currently operated by various bioenergy companies in Malaysia.

Table 2. Key actors in the biomass innovation system (BIS) in Malaysia [52].

\begin{tabular}{|l|c|c|c|l|}
\hline Plant owner/operator & Location & $\begin{array}{c}\text { Capacity } \\
\text { (MW) }\end{array}$ & Technology & Fuel \\
\hline Alaf Ekspresi & Sabah & 8 & Steam turbines & Palm waste \\
\hline Bumi biopower & Perak & 6 & Steam turbines & Palm waste \\
\hline Jana Landfill & Selangor & 2 & Gas turbines & Biogas \\
\hline Kina Biopower & Sabah & 11.5 & Steam turbines & Palm waste \\
\hline Naluri Ventures & Johor & 12 & Steam turbines & Palm waste \\
\hline Potensi Gaya & Sabah & 7 & Steam turbines & Palm waste \\
\hline Recycle Energy & Selangor & 8.9 & Gas turbines & Biogas \\
\hline Seguntor Bioenergy & Sabah & 11.5 & Steam turbines & Palm waste \\
\hline TSH Bio Energy & Sabah & 14 & Steam turbines & Palm waste \\
\hline $\begin{array}{l}\text { Bentong Biomass } \\
\text { Energy }\end{array}$ & Pahang & 1.2 & Steam Turbines & Palm \\
\hline Mensilin Holdings & Selangor & 1.2 & Steam Turbines & Palm waste \\
\hline SEO Energy Sdn Bhd & Sabah & 1.2 & Steam Turbines & Palm waste \\
\hline LDEO Energy & Sabah & 1.2 & Steam Turbines & Palm waste \\
\hline Kwantas Oil & Sabah & 9.8 & Steam Turbines & Palm waste \\
\hline LH Kiln D Moulding & Johor & 0.6 & Steam Turbines & Palm waste \\
\hline Total & $\mathbf{9 6 . 1}$ & & \\
\hline
\end{tabular}

As observed, the current operations of the outlined companies involve the utilization of OPW and wood chips for generating biomass-based renewable energy using 
steam and gas turbines. The data in Tables 1 and 2 indicate that the BETs innovation system in Malaysia consists of a relatively large number of active stakeholders. According to Hekkert et al. [37], the existence of large numbers of entrepreneurs is a fundamental sign of a healthy innovation system as the nonexistence of entrepreneurs can lead to the failure of other functions in the innovation system. Furthermore, the success of an innovation system significantly depends on the networks formed by entrepreneurs and their ability to coordinate all the other functions of the innovation system [37].

Despite the healthy landscape of entrepreneurs, the biomass innovation system (BIS) is limited to $96 \mathrm{MW}$ of installed and operational capacity. According to Oh et al. [53], Malaysia can potentially generate an estimated 1,340 MW of renewable electricity from biomass. This indicates that entrepreneurial activities in Malaysia are well short of the policy guidelines of the $5^{\text {th }}$ Fuel Diversification Strategy of the $8^{\text {th }}$ Malaysia Plan (8MP) aimed at generating 5\% of the nation's electricity from RETs [54]. One potential solution will be to retrofit oil palm mills (OPM) operating in the country to generate bioelectricity for integration into the national grid $[30,55]$.

\subsection{Knowledge Development}

The development of scientific and technological knowledge base is fundamental to an innovation system in any modern economy. It refers to all the processes and mechanisms of learning which significantly influence the growth and development of innovation systems [56]. Hence, learning mechanisms are the heart of the innovation process particularly because they influence knowledge development through $R \& D$. The learning process of FIS involves the learning by doing, interacting, searching and using; which emphasizes the importance of R\&D to the success of an innovation system [57]. The study by Zangwill and Kantor [58], posits that the knowledge development function of an innovation system can be examined using three indicators namely; Patents, R\&D projects, and $R \& D$ investments. Since $R \& D$ is vital to innovation, a comprehensive assessment of the patents and intellectual property rights in Malaysia is necessary to assess the knowledge development function. Table 3 presents a list of registered patents in science, technology, and engineering in Malaysia from 2006 to 2016 [59]. 
Table 3. Technology Patents Granted in Malaysia from 2006-2016 [59].

\begin{tabular}{|c|c|c|c|c|c|c|c|c|c|}
\hline \multirow{2}{*}{ YEAR } & \multicolumn{7}{|c|}{ SECTION } & \multirow{2}{*}{ TOTAL } \\
\cline { 2 - 9 } & $\mathbf{A}$ & $\mathbf{B}$ & $\mathbf{C}$ & $\mathbf{D}$ & $\mathbf{E}$ & $\mathbf{F}$ & $\mathbf{G}$ & $\mathbf{H}$ & \\
\hline 2006 & 948 & 1,155 & 1,275 & 101 & 197 & 448 & 1,042 & 1,583 & $\mathbf{6 , 7 4 9}$ \\
\hline 2007 & 1,179 & 1,213 & 1,748 & 109 & 221 & 407 & 883 & 1,223 & $\mathbf{6 , 9 8 3}$ \\
\hline 2008 & 423 & 421 & 451 & 33 & 98 & 159 & 293 & 364 & $\mathbf{2 , 2 4 2}$ \\
\hline 2009 & 656 & 633 & 837 & 53 & 119 & 185 & 488 & 497 & $\mathbf{3 , 4 6 8}$ \\
\hline 2010 & 364 & 390 & 599 & 22 & 75 & 125 & 274 & 328 & $\mathbf{2 , 1 7 7}$ \\
\hline 2011 & 404 & 402 & 693 & 28 & 90 & 126 & 283 & 366 & $\mathbf{2 , 3 9 2}$ \\
\hline 2012 & 445 & 424 & 722 & 25 & 72 & 101 & 328 & 384 & $\mathbf{2 , 5 0 1}$ \\
\hline 2013 & 523 & 393 & 840 & 36 & 98 & 108 & 315 & 378 & $\mathbf{2 , 6 9 1}$ \\
\hline 2014 & 538 & 430 & 729 & 27 & 154 & 150 & 331 & 403 & $\mathbf{2 , 7 6 2}$ \\
\hline 2015 & 542 & 494 & 642 & 25 & 161 & 198 & 352 & 494 & $\mathbf{2 , 9 0 8}$ \\
\hline Oct-16 & 537 & 359 & 881 & 30 & 129 & 127 & 213 & 360 & $\mathbf{2 , 6 3 6}$ \\
\hline TOTAL & $\mathbf{6 , 5 5 9}$ & $\mathbf{6 , 3 1 4}$ & $\mathbf{9 , 4 1 7}$ & $\mathbf{4 8 9}$ & $\mathbf{1 , 4 1 4}$ & $\mathbf{2 , 1 3 4}$ & $\mathbf{4 , 8 0 2}$ & $\mathbf{6 , 3 8 0}$ & $\mathbf{3 7 , 5 0 9}$ \\
\hline
\end{tabular}

Section A: Human Necessities; Section B: Performing Operations \& Transportation; Section C: Chemistry \& Metallurgy; Section D: Textiles \& Paper; Section E: Fixed Construction; Section F: Mechanical Engineering, Lighting, Heating, Weapons \& Blasting; Section G: Physics; Section H: Electricity.

The data presented indicates that the academia is actively involved in $R \& D$ and can potentially complement the biofuels and bioenergy industry in Malaysia. In addition to entrepreneurs, private institutions, academic institutions also play a vital role in the development of innovations systems. A list of academic institutions currently carrying out research into biomass-based energy technologies in Malaysia is presented in Table 4. 
Table 4. Malaysian academic institutions conducting biomass research.

\begin{tabular}{|l|l|l|}
\hline Institutions & Abbreviation & Area of Research \\
\hline Universiti Kebangsaan Malaysia & UKM & $\begin{array}{l}\text { Jatropha oil extraction, } \\
\text { heterogeneous catalysis }\end{array}$ \\
\hline Universiti Sains Malaysia & USM & $\begin{array}{l}\text { Heterogeneous catalysis and } \\
\text { Biodiesel from Jatropha }\end{array}$ \\
\hline University Putra Malaysia & UPM & Biodiesel/Biofuels Research \\
\hline University Malaya & UM & $\begin{array}{l}\text { Biomass Conversion, } \\
\text { Biodiesel/Biofuels Research }\end{array}$ \\
\hline University Technology Malaysia & UTM & $\begin{array}{l}\text { Biomass Conversion, Hydrogen, } \\
\text { Fuel Processing }\end{array}$ \\
\hline University Technology Petronas & UTP & Biodiesel/Biofuels Research \\
\hline International Islamic University & IIU & Biodiesel/Biofuels Research \\
\hline University Malaysia Sabah & UMS & Biodiesel/Biofuels Research \\
\hline
\end{tabular}

In addition to active university research, a number of institutes in the country are engaged in cutting-edge research in other RETs. In addition, the Malaysian government has been actively financing projects and providing policy guidelines for the development and diffusion of RETs in the country. A good example is the Feed-in Tariff scheme for biomass and other RETs managed by the Sustainable Energy Development Authority of Malaysia (SEDA Malaysia) [60]. Similarly, the Green Technology Financing Scheme (GTFS) is a funding scheme established in 2010 by the Government of Malaysian Prime Minister [61]. Other key policies for RETs development in Malaysia will be identified and highlighted in the Function: Knowledge Diffusion through Networks.

\subsection{Knowledge Diffusion through Networks}

The role of networks is to exchange scientific knowledge and technological information vital to the success of the innovation system [50, 62]. The knowledge diffusion function is an integration of technological insights, government policies, norms, and values - all referred to as 'learning by interacting' [37]. The integration of these 
networks not only augments the knowledge base of the innovation system but also the perception of what is possible and desirable in terms of future developments and investment choices [62]. Furthermore, the size of networks, extent of public-private collaborations, number of actors and stakeholders is evidence of the level of knowledge development and diffusion [37]. In Malaysia, biomass energy has been promoted by a number of key policies and regulatory guidelines aimed at stimulating the development and diffusion of RETs in the country. Table 5 presents a summary of the key laws, policies and implementation guidelines promulgated by the Malaysian government for RETs development over the years.

Table 5. Malaysian Renewable Energy Policies [47, 63, 64].

\begin{tabular}{|c|c|c|}
\hline Policy Directive & $\begin{array}{c}\text { Year } \\
\text { Establis } \\
\text { hed }\end{array}$ & Aim and Objectives \\
\hline $\begin{array}{l}\text { National Energy Policy } \\
\text { (NEP) }\end{array}$ & 1979 & $\begin{array}{l}\text { Ensure an efficient, secure and environmentally } \\
\text { sustainable supply of clean energy. }\end{array}$ \\
\hline $\begin{array}{l}\text { Four Fuel Diversification } \\
\text { Policy (4FDP) }\end{array}$ & 1981 & $\begin{array}{l}\text { Promote fuel diversification, reduce dependence on } \\
\text { oil and increased emphasis on gas, hydro and coal. }\end{array}$ \\
\hline $\begin{array}{l}\text { Seventh Malaysian Plan } \\
(7 \mathrm{MP})\end{array}$ & 1996 & $\begin{array}{l}\text { To achieve } 5 \% \text { Electric energy demand from RETs } \\
\text { by } 2005 \text { and promote energy efficiency. }\end{array}$ \\
\hline $\begin{array}{l}5^{\text {th }} \text { Fuel Diversification } \\
\text { Policy (FDP) }\end{array}$ & 2000 & $\begin{array}{l}\text { Reduce overdependence on fossil fuels. Highlight the } \\
\text { nation's biofuel potential and balance energy mix } \\
\text { with RETs. }\end{array}$ \\
\hline $\begin{array}{l}\text { Renewable Energy as } \\
\text { Fifth Fuel Policy }\end{array}$ & 2000 & $\begin{array}{l}\text { To highlight the potentials of biomass, biogas and } \\
\text { other renewable energy resources. }\end{array}$ \\
\hline $\begin{array}{l}\text { Energy Commission Act } \\
\text { (ECA) }\end{array}$ & 2001 & $\begin{array}{l}\text { To regulate the energy industry in Peninsular } \\
\text { Malaysia and Sabah and ensure energy efficiency. }\end{array}$ \\
\hline $8^{\text {th }}$ Malaysian Plan (8MP) & $\begin{array}{l}2001- \\
2005\end{array}$ & $\begin{array}{l}\text { To promote sustainable development and achieve } 5 \\
\% \text { electricity from RETs. }\end{array}$ \\
\hline $\begin{array}{l}\text { Small Renewable Energy } \\
\text { Power Program (SREP) }\end{array}$ & 2001 & $\begin{array}{l}\text { Encourage the utilization of RETs for power } \\
\text { generation and reduce overdependence on fossil } \\
\text { fuels. }\end{array}$ \\
\hline
\end{tabular}




\begin{tabular}{|c|c|c|}
\hline $\begin{array}{l}\text { Renewable Energy Power } \\
\text { Purchase Agreement } \\
\text { (REPPA) }\end{array}$ & 2001 & $\begin{array}{l}\text { To provide an equitable pricing policy for purchase } \\
\text { of energy from RETs companies and integration of } \\
\text { RETs into the national electricity grid. }\end{array}$ \\
\hline $9^{\text {th }}$ Malaysian Plan (9MP) & $\begin{array}{l}2006- \\
2010\end{array}$ & $\begin{array}{l}\text { Review electricity prices, fossil fuel dependency, } \\
\text { increase the share of RETs in the energy mix, and } \\
\text { access to funding for RETs. }\end{array}$ \\
\hline $\begin{array}{l}\text { National Biofuel Policy } \\
\text { (NBP) }\end{array}$ & 2006 & $\begin{array}{l}\text { To enhance extensive growth and development of the } \\
\text { biofuels industry. }\end{array}$ \\
\hline $\begin{array}{l}\text { Malaysian Biofuel } \\
\text { Industry Act }\end{array}$ & 2007 & $\begin{array}{l}\text { Regulate, facilitate and develop the biofuels industry. } \\
\text { Issue licences and reduce administrative barriers for } \\
\text { growth in the sector }\end{array}$ \\
\hline $\begin{array}{l}\text { National Green } \\
\text { Technology Policy } \\
\text { (NGTP) }\end{array}$ & 2009 & $\begin{array}{l}\text { Strengthen institutional framework, provide a } \\
\text { favourable environment for green energy technology } \\
\text { R\&D and increase public awareness of RETs. } \\
\text { Establish the Green Technology Financing Scheme } \\
\text { (GTFS). }\end{array}$ \\
\hline $\begin{array}{l}\text { Renewable Energy Policy } \\
\text { and Action Plan (REPAP) }\end{array}$ & 2010 & $\begin{array}{l}\text { Promote the use of locally generated renewable } \\
\text { energy, ensure energy security and fuel supply } \\
\text { independence. Address market failures and policy } \\
\text { inconsistencies and increase share of RE in the } \\
\text { energy mix. }\end{array}$ \\
\hline $\begin{array}{l}\text { National Biomass } \\
\text { Strategy (NBS2020) }\end{array}$ & 2011 & $\begin{array}{l}\text { Promote the valorisation of oil palm wastes, reduce } \\
\text { GHG emissions, meet RETs targets and generate } \\
66,000 \text { jobs. }\end{array}$ \\
\hline $\begin{array}{l}\text { Renewable Energy Act } \\
\text { (REA) }\end{array}$ & 2011 & $\begin{array}{l}\text { Ensure growth and development RETs in Malaysia, } \\
\text { increase funds for RETs projects, reduce GHG } \\
\text { emissions from fossil fuels use and electricity } \\
\text { generation. Establish the Feed-in Tariff Scheme. }\end{array}$ \\
\hline $\begin{array}{l}\text { Tenth Malaysia Plan } \\
(10 \mathrm{MP})\end{array}$ & $\begin{array}{l}2011- \\
2015\end{array}$ & $\begin{array}{l}\text { New policy directions, strategies, and programs to } \\
\text { ensure knowledge abilities, innovation and } \\
\text { sustainability. }\end{array}$ \\
\hline $\begin{array}{l}\text { Eleventh Malaysia Plan } \\
\text { (11MP) }\end{array}$ & $\begin{array}{l}2016- \\
2020\end{array}$ & $\begin{array}{l}\text { Promote the use of sustainable energy for growth and } \\
\text { development in Malaysia. Ensure energy security and } \\
\text { management of resources in the country by } 2020 \text {. }\end{array}$ \\
\hline
\end{tabular}


The key policies and regulatory guidelines particularly the $8^{\text {th }}-11^{\text {th }}$ Malaysia Plans outlined in Table 5 have been pivotal to RETs development in the country. In spite of the favourable environment, policy backing and government support, RETs diffusion into the Malaysia energy mix have remained low over the years. According to Strategy Paper 17 of the 11MP, the share of RETs has grown from $0.07 \%$ to $0.33 \%$ from $2006-2013$ whereas that for biomass sparsely improved from $0.55 \%$ to $0.56 \%$ within the same period [65]. Similarly, the SEDA Agency reports that energy from biomass and solid bio-wastes account for $87.90 \mathrm{MW}$ or $17.89 \%$ of the $491.12 \mathrm{MW}$ of installed RETs capacity in Malaysia. As a result, Biomass and RETs still account for a small fraction (2.1\% in 2015) of energy generation in Malaysia [65]. This is below the 5\% RETs electricity target designated in 8th Malaysian Plan (8MP) which can be attributed to several factors [54].

The slow diffusion and development of RETs can be ascribed to the plethora of energy laws, and policies directives. The existence of which create conflicting roles for supervisory or implementation agencies involved in the development, diffusion, and administration of energy policies in Malaysia. For example in 2001 the ECA, 8MP, SREP, REPPA were established. As observed in Table 5 the objectives of the ECA, SREP, and REPPA are similar and can be merged into one encompassing law administered by the Ministry of Energy, Green Technology and Water (KeTTHA). Currently, KeTTHA, SEDA, and the ministries of Environment and Statistics are all charged with implementing RETs laws and policies in Malaysia. Likewise, the NBP, NGTP, and REA can be merged for more effective implementation of RETs directives with the proposed Energy Commission tasked with supervisory or implementation.

\subsection{Guidance of Search}

The guidance of search is an interactive process aimed at fostering the exchange of ideas amongst technology producers, technology users and other players such as advocacy or lobby groups, think tanks within the innovation system [37]. It emphasizes the need to set realistic targets and utilizing often limited resources to the most feasible technologies. The implementation of this function is the responsibility of individuals, government, and industry in the innovation system. The function also serves as a "selection process" aimed at creating high expectations and attracting future investments through effective resources utilization to create novel technologies and markets. Table 6 
presents an overview of the governments RETs and GHGs emission targets by 2050. As observed in Table 6 , the government plans to generate $11.5 \mathrm{MW}$ of renewable electric energy by 2050 which serves to reinforce the government's commitment to the RETs sector. According to Hekkert et al. [37], such policy directives "helps to broaden the mental map" of the current and future expectations - a scenario that helps to reassure potential investors.

Table 6. Policy Directives of the Renewable Energy Act 2010 [47, 54].

\begin{tabular}{|c|c|c|c|c|c|}
\hline Year & $\begin{array}{c}\text { Cumulative } \\
\text { Total RE (MW) }\end{array}$ & $\begin{array}{c}\text { Share of } \\
\text { RE (\%) }\end{array}$ & $\begin{array}{c}\text { Annual RE } \\
(\mathbf{G W h})\end{array}$ & $\begin{array}{c}\text { RE Mix } \\
\mathbf{( \% )}\end{array}$ & $\begin{array}{c}\mathbf{C O}_{2} \\
\text { Reduction }\end{array}$ \\
\hline 2015 & 975 & 6 & 5,374 & 5 & $3,385,406$ \\
\hline 2020 & 2,065 & 10 & 11,227 & 9 & $7,073,199$ \\
\hline 2030 & 3,484 & 13 & 16,512 & 10 & $10,402,484$ \\
\hline 2050 & 11,544 & 34 & 25,579 & 13 & $16,114,871$ \\
\hline
\end{tabular}

\subsection{Market Formation}

Profit motivation is a key factor for introducing new technologies such as RETs. Hence markets, manufacturers, suppliers, and technology users are required for innovative technologies to thrive since novel technologies often experience competition from established technologies $[37,66]$. Furthermore, the market availability supports the formulation and articulation of demand for new technologies. However, the diffusion of novel "niche" technologies such as RETs is a complicated process typically influenced by existing "regime" technologies such as fossil fuels. The regime technologies also called "prevailing technologies" are products of evolutionary improvements in terms of accumulated knowledge, capital outlays, infrastructure, and availability of skilled labour, production routines, social norms, regulation, and lifestyles [67, 68].

There are avenues available whereby the Malaysian government can support biomass energy technologies by either creating protective niche markets or instituting incentives and tax regimes. The introduction of more market-enabling policies such as Feed-in Tariffs (FiTs) and the Green Technology Financing Scheme (GTFS) will further catalyse RETs in the country. The FiTs scheme needs to be revisited as the rates have 
remained relatively stagnant at $0.27-0.31 \mathrm{RM}$ per $\mathrm{kWh}$ from 2012 to 2017 [60]. Favourable rates will encourage OPMs, most of which already generate electricity from OPW biomass, to invest in retrofits for renewable energy production and integration into the national grid. Furthermore, financing for GTFS needs to be improved from its current level of RM 3.5 Billion to reflect the current economic climate.

\subsection{Resources Mobilization}

The allocation of funds and human capital is vital to the survival of new technologies within an innovation system [37]. This is vital to the process of knowledge development through the financing of long-term $R \& D$ programs, grants for universities and other research institutions within the innovation system. In Malaysia, the government has voted the sum of RM 1 billion (One Billion Ringgit Malaysia) towards its Renewable Energy Fund as part of the Renewable Energy Act established in 2010 [60]. Other sources of finance include loans from commercial banks, Developmental Finance Institutions (DFI), or equity financing from capital markets, angel investors, venture capital firms, technology manufacturers and suppliers.

\subsection{Creation of Legitimacy}

Incumbent technologies often possess the advantage of undergoing a process of increasing returns, thereby associating the new technologies with high price or low utility [50]. Therefore, niche technologies must liaise with lobby groups to counteract the resistance from incumbent regime technologies. In effect, the survival of new technologies significantly depends on the financial resources and advocacy campaigns of lobby groups [37]. In Malaysia, the interests of biomass energy companies are supported by organisations such as Palm Oil Refiners Association of Malaysia (PORAM), Malaysian Palm Oil Association (MPOA), Malaysian Palm Oil Board (MPOB), and Round Table on Sustainable Palm Oil (RSPO) [8, 69]. The role of these organisations is to promote the interests of the oil palm growers and stakeholders in Malaysia. However, none is responsible for promoting biomass power or electricity generation which effectively indicates that the lobbying and advocacy coalition activities of the biomass innovation system (BIS) are Malaysia is lacking. 


\subsection{Summary and Conclusions}

The entrepreneurial activities, knowledge development, and resources mobilization functions are well established in the Malaysian biomass innovation system (BIS) as outlined by this study. The presence of a large number of actors, networks, and institutions is evidence of the success of these functions. However, the glut of entrepreneurs has prevented the formation of "prime movers"- actors with the technical, financial and political clout to significantly catalyse the emergence of novel technologies [50]. In addition, the increased competition in the network potentially shrinks the renewable energy market and in the long-term, the profitability of actors in the innovation system. This can discourage new entrants with novel innovation and ideas which can be an undesirable dynamic, particularly in the capital-intensive and high-risk RETs landscape. The learning methods outlined by Kamp et al. [57], are evident in Malaysian academia signifying the development of knowledge development function. The study reveals that numerous research groups are actively engaged in biomass energy technologies for power generation. Similarly, the government and related agencies are actively providing financial and infrastructural support through research grants and funding incentives for RETs research and development in Malaysia. This indicates that the resources mobilization function is also well established within this innovation system. However, the guidance of search, the creation of legitimacy, knowledge diffusion, and market formation functions are weak and lag behind the other outlined functions. In particular, the guidance of search and creation of legitimacy functions are not well developed in the biomass innovation system in Malaysia. Currently, advocacy efforts are primarily geared towards oil palm and palm oil products, ignoring the immense potential of diversifying their operations into clean power and electricity generation from the OPW generated in tow. As a result, advocacy or lobby groups in the innovation system (IS) need to intensify efforts in influencing government policy towards biomass energy technologies in Malaysia. Furthermore, the lobby groups need to redirect efforts and resources toward influencing related technology financing, environmental sustainability, biofuel subsidies, and tax exemptions for stakeholders in the BIS in Malaysia. This is corroborated by Ahmad et al. [70], who posit that RETs diffusion can only be achieved by reducing the cost of the technologies, related energy services and the removal of market distortions such as fuel subsidies. As pointed out earlier, the Feed-in Tariff for biomass and RETs 
needs to be reviewed. This will potentially encourage independent power producers such as oil palm mills to invest in the technologies for the production and integration of bioelectricity. Based on analysis of the BIS using the functions of innovation systems (FIS) approach, the authors have outlined the key factors hindering the BIS in Malaysia. These include; fossil fuel subsidies, inconsistent or conflicting policies, financing bottlenecks, a weak collaboration between academia-industry. However, the outlined challenges can be addressed by the gradual revision of current fuel subsidies, streamlining the RETs implementation and supervisory agencies, reducing the bureaucratic constraints hindering access to funds and hampering investments in RETs development and diffusion in the country. In addition, knowledge information centres (KICs) need to be established to foster the development of ideas, technical know-how and industry-based experience of RETs between the actors and networks in Malaysia. Lastly, lobby groups need to encourage and play a more significant role in policy formulation and creating greater awareness on the benefits of RETs in Malaysia.

\section{References}

[1] Suganthi, L., and Samuel, A.A. (2012). Energy models for demand forecastingA review. Renewable and sustainable energy reviews 16, 1223-1240.

[2] OECD Working Paper. (2012). The Global Value of Coal In IEA Coal Industry Advisory Board OECD, Paris.

[3] van der Hoeven, M. (2013). World Energy Outlook 2013.

[4] Kaygusuz, K. (2009). Energy and environmental issues relating to greenhouse gas emissions for sustainable development in Turkey. Renewable and Sustainable Energy Reviews 13, 253-270.

[5] Veziroğlu, T.N., and Şahi, S. (2008). 21st Century's energy: Hydrogen energy system. Energy conversion and management 49, 1820-1831.

[6] Hossain, A., and Badr, O. (2007). Prospects of renewable energy utilisation for electricity generation in Bangladesh. Renewable and Sustainable Energy Reviews 11, 1617-1649.

[7] IEA-WEO. (2013). World Energy Outlook FactSheet: How will global energy markets evolve to 2035?, IEA. 
[8] Johari, A., Nyakuma, B.B., Mohd Nor, S.H., Mat, R., Hashim, H., Ahmad, A., Yamani Zakaria, Z., and Tuan Abdullah, T.A. (2015). The challenges and prospects of palm oil based biodiesel in Malaysia. Energy 81, 255-261.

[9] IRENA. (2014). Global Bioenergy Supply and Demand Projections: Working paper for REmap 2030, 1st Ed. ed., pp 1-76, International Renewable Energy Agency (IRENA), Abu Dhabi, UAE.

[10] McKendry, P. (2002). Energy production from biomass (part 1): overview of biomass. Bioresource Technology 83, 37-46.

[11] Demirbas, A. (2004). Combustion characteristics of different biomass fuels. Progress in Energy and Combustion Science 30, 219-230.

[12] Fritsche, U., Kampman, B., and Bergsma, G. (2009). Better use of biomass for energy. Position paper of IEA RETD and IEA Bioenergy.

[13] Demirbas, A. (2009). Progress and recent trends in biodiesel fuels. Energy conversion and management 50, 14-34.

[14] Lehmann, J. (2007). A handful of carbon. Nature 447, 143-144.

[15] Johnson, E. (2009). Goodbye to carbon neutral: Getting biomass footprints right. Environmental impact assessment review 29, 165-168.

[16] Wang, L., Weller, C.L., Jones, D.D., and Hanna, M.A. (2008). Contemporary issues in thermal gasification of biomass and its application to electricity and fuel production. Biomass and Bioenergy 32, 573-581.

[17] Chang, J., Fu, Y., and Luo, Z. (2012). Experimental study for dimethyl ether production from biomass gasification and simulation on dimethyl ether production. Biomass and Bioenergy 39, 67-72.

[18] Baskar, C., Baskar, S., and Dhillon, R.S. (2012). Biomass conversion: The interface of biotechnology, chemistry and materials science, Springer Science \& Business Media.

[19] Nyakuma, B.B. (2015). Thermogravimetric and Kinetic Analysis of Melon (Citrullus colocynthis L.) Seed Husk Using the Distributed Activation Energy Model. Environmental and Climate Technologies 15, 77-89.

[20] Malaysian Palm Oil Board (MPOB). (2011). Oil Palm Planted Areas as at September 2011. 
[21] Yan, W. (2017). A Makeover For The World's Most Hated Crop. Nature 543, 306-308.

[22] Malaysian Palm Oil Board (MPOB). (2011). Annual and Forecast of Crude Palm Oil Production (Tonnes) 2010 and 2011.

[23] Khatun, R., Reza, M.I.H., Moniruzzaman, M., and Yaakob, Z. (2017). Sustainable oil palm industry: The possibilities. Renewable and Sustainable Energy Reviews 76, 608-619.

[24] Nyakuma, B.B., Ahmad, A., Johari, A., Abdullah, T.A., Oladokun, O., and Alkali, H. (2017). Fluidised Bed Gasification and Chemical Exergy Analysis of Pelletised Oil Palm Empty Fruit Bunches. Chemical Engineering Transactions 56, 11591164.

[25] Basiron, Y. (2007). Palm oil production through sustainable plantations. European Journal of Lipid Science and Technology 109, 289-295.

[26] Nyakuma, B.B., Ahmad, A., Johari, A., Tuan, T.A., Oladokun, O., and Aminu, D.Y. (2015). Non-Isothermal Kinetic Analysis of Oil Palm Empty Fruit Bunch Pellets by Thermogravimetric Analysis. Chemical Engineering Transactions 45, 1327-1332.

[27] Nyakuma, B.B., Mazangi, M., Tuan Abdullah, T.A., Johari, A., Ahmad, A., and Oladokun, O. (2014). Gasification of Empty Fruit Bunch Briquettes in a Fixed Bed Tubular Reactor for Hydrogen Production. Applied Mechanics and Materials 699, 534-539.

[28] Poku, K. (2002). Small-scale palm oil processing in Africa, Vol. 148, Food \& Agriculture Org.

[29] Nyakuma, B.B., Oladokun, O.A., Johari, A., Ahmad, A., and Abdullah, T.A.T. (2014). A Simplified Model for Gasification of Oil Palm Empty Fruit Bunch Briquettes. Jurnal Teknologi 69, 7-9.

[30] Sulaiman, F., Abdullah, N., Gerhauser, H., and Shariff, A. (2011). An outlook of Malaysian energy, oil palm industry and its utilization of wastes as useful resources. Biomass and bioenergy 35, 3775-3786.

[31] Nyakuma, B.B. (2015). Bioelectricity potential of oil palm waste in Malaysia, In 3rd International Conference Research \& Education in Natural Sciences (HERTSPO 2015) (Bekteshi, A., Ed.), Shkodra BENA. 
[32] Shafie, S., Mahlia, T., Masjuki, H., and Ahmad-Yazid, A. (2012). A review on electricity generation based on biomass residue in Malaysia. Renewable and Sustainable Energy Reviews 16, 5879-5889.

[33] Omer, A.M. (2008). Energy, Environment and Sustainable development. Renewable and Sustainable Energy Reviews 12, 2265-2300.

[34] Nyakuma, B.B., Johari, A., Ahmad, A., and Abdullah, T.A.T. (2014). Comparative analysis of the calorific fuel properties of Empty Fruit Bunch Fiber and Briquette. Energy Procedia 52, 466-473.

[35] Olivier, J.G.J., Janssens-Maenhout, G., Muntean, M., and Peters, J.A.H.W. (2017). Trends in global CO2-emissions - 2016 Report, p 86, PBL Netherlands Environmental Assessment Agency European Commission, , Joint Research Centre (EC-JRC), The Hague, Netherlands.

[36] National Biomass Strategy 2020 (NBS-2020). (2013). New wealth creation for Malaysia’s biomass industry, 2 ed., pp 1-20, Agensi Inovasi Malaysia (AIM), Kuala Lumpur, Malaysia.

[37] Hekkert, M.P., Suurs, R.A., Negro, S.O., Kuhlmann, S., and Smits, R. (2007). Functions of innovation systems: A new approach for analysing technological change. Technological forecasting and social change 74, 413-432.

[38] Smits, R., and Kuhlmann, S. (2004). The rise of systemic instruments in innovation policy. International Journal of Foresight and Innovation Policy 1, 432.

[39] Bergek, A., Hekkert, M., and Jacobsson, S. (2008). Functions in innovation systems: A framework for analysing energy system dynamics and identifying goals for system-building activities by entrepreneurs and policy makers. Innovation for a low carbon economy: economic, institutional and management approaches 79.

[40] Hekkert, M.P., Harmsen, R., and de Jong, A. (2007). Explaining the rapid diffusion of Dutch cogeneration by innovation system functioning. Energy Policy $35,4677-4687$.

[41] Bergek, A., Jacobsson, S., Carlsson, B., Lindmark, S., and Rickne, A. (2008). Analyzing the functional dynamics of technological innovation systems: A scheme of analysis. Research policy 37, 407-429. 
[42] Edquist, C. (2011). Design of innovation policy through diagnostic analysis: identification of systemic problems (or failures). Industrial and Corporate Change, dtr060.

[43] Kamp, L.M. (2008). Socio-technical analysis of the introduction of wind power in the Netherlands and Denmark. International Journal of Environmental Technology and Management 9, 276-293.

[44] Negro, S.O., Suurs, R.A., and Hekkert, M.P. (2008). The bumpy road of biomass gasification in the Netherlands: Explaining the rise and fall of an emerging innovation system. Technological forecasting and social change 75, 57-77.

[45] Negro, S.O., Hekkert, M.P., and Smits, R.E. (2007). Explaining the failure of the Dutch innovation system for biomass digestion - a functional analysis. Energy policy $35,925-938$.

[46] Negro, S.O., and Hekkert, M.P. (2008). Explaining the success of emerging technologies by innovation system functioning: the case of biomass digestion in Germany. Technology Analysis \& Strategic Management 20, 465-482.

[47] Hashim, H., and Ho, W.S. (2011). Renewable energy policies and initiatives for a sustainable energy future in Malaysia. Renewable and Sustainable Energy Reviews 15, 4780-4787.

[48] Kardooni, R., Yusoff, S.B., and Kari, F.B. (2015). Barriers to Renewable Energy Development: Five Fuel Policy in Malaysia. Energy \& Environment 26, 13531361.

[49] Bergek, A., Jacobsson, S., Carlsson, B., Lindmark, S., and Rickne, A. (2005). Analyzing the dynamics and functionality of sectoral innovation systems-a manual, In DRUID Tenth Anniversary Summer Conference, pp 27-29.

[50] Jacobsson, S., and Johnson, A. (2000). The diffusion of renewable energy technology: an analytical framework and key issues for research. Energy policy 28, 625-640.

[51] Umar, M.S., Jennings, P., and Urmee, T. (2014). Generating renewable energy from oil palm biomass in Malaysia: The Feed-in Tariff policy framework. biomass and bioenergy 62, 37-46.

[52] Babcock \& Wilcox Vølund. (2017). Biomass Energy Plants 1996 - 2017, 1 ed., p 2, Babcock \& Wilcox Vølund A/S, EsbjergØ, Denmark. 
[53] Oh, T.H., Pang, S.Y., and Chua, S.C. (2010). Energy policy and alternative energy in Malaysia: issues and challenges for sustainable growth. Renewable and Sustainable Energy Reviews 14, 1241-1252.

[54] Economic Planning Unit (EPU). (2006). 8th Malaysia Plan,. Malaysian National Printing.

[55] Kasivisvanathan, H., Ng, R.T., Tay, D.H., and Ng, D.K. (2012). Fuzzy optimisation for retrofitting a palm oil mill into a sustainable palm oil-based integrated biorefinery. Chemical engineering journal 200, 694-709.

[56] Lundvall, B. (1992). National Systems of Innovation: Towards a Theory of Innovation and Interactive Learning (Pinter, New York).

[57] Kamp, L.M., Smits, R.E., and Andriesse, C.D. (2004). Notions on learning applied to wind turbine development in the Netherlands and Denmark. Energy policy 32, 1625-1637.

[58] Zangwill, W.I., and Kantor, P.B. (2000). The learning curve: a new perspective. International transactions in operational research 7, 595-607.

[59] Perbadanan Harta Intelek Malaysia (MyIPO). (2017). Technology Patents Granted in Malaysia 2006 - 2016, Government of Malaysia, Putrajaya, Malaysia.

[60] Sustainable Energy Development Authority (SEDA). (2017). Feed-in Tariff scheme Government of Malaysia, Putraja, Malaysia.

[61] Malaysian Green Technology Corporation (MGTC). (2017). Green Technology Financing Scheme (GTFS), Government of Malaysia, Putrajaya, Malaysia.

[62] Saxenian, A. (1994). Culture and Competition in Silicon Valley and Route 128, Harvard University Press, Cambridge, MA (USA).

[63] Economic Planning Unit (EPU). (2017). Development Policies and Key Policies of Malaysia, Government of Malaysia, Putraja, Malaysia.

[64] UNDP Malaysia. (2007). Malaysia Generating Renewable Energy from palm Oil Wastes, Malaysia.

[65] Economic Planning Unit (EPU). (2016). 11th Malaysia Plan, (Department, P.M., Ed.), Government of Malaysia (GoM), Putrajaya, Malaysia.

[66] Rosenberg, N. (1972). Factors affecting the diffusion of technology. Explorations in economic history 10, 3-33. 
[67] Kemp, R. (1994). Technology and the transition to environmental sustainability: the problem of technological regime shifts. Futures 26, 1023-1046.

[68] Geels, F.W. (2002). Technological transitions as evolutionary reconfiguration processes: a multi-level perspective and a case-study. Research policy 31, 12571274.

[69] Hai, T.C. (2002). The Palm Oil Industry in Malaysia: From Seed to Frying Pan, pp 1-145, World Wildlife Fund Malaysia, Selangor, Malaysia.

[70] Ahmad, S., Ab Kadir, M.Z.A., and Shafie, S. (2011). Current perspective of the renewable energy development in Malaysia. Renewable and Sustainable Energy Reviews 15, 897-904. 